\title{
Young Children's Judgments of Counter-Intuitive Information and Its Relation with Executive Function
}

\author{
Yuri Jeong ${ }^{1}$, Jeein Jeong ${ }^{2}$ \\ M. A., Department of Child Development and Family Studies, Pusan National University, Busan, Korea ${ }^{1}$ \\ Assistant Professor, Department of Child Development and Family Studies, Pusan National University \& \\ Adjunct Researcher, Research Institute of Human Ecology, Pusan National University, Busan, Korea² \\ 직관에 반하는 정보에 대한 유아의 판단과 실행기능의 관련성 \\ 정유리 ${ }^{1}$, 정지인 ${ }^{2}$ \\ 부산대학교 아동가족학과 석사 ${ }^{1}$, 부산대학교 아동가족학과 조교수 및 부산대학교 생활환경연구소 겸임연구원 ${ }^{2}$
}

Objectives: This study examined young children's judgments of counter-intuitive information, and whether their judgments relate to the executive function and theory of mind.

Methods: Ninety-two children aged 3 to 6 years were provided with counter-intuitive information that the smallest doll was the heaviest among five Russian dolls in a one-on-one interview with a researcher. Subsequently, how children judged the weights of the dolls, whether they did an experiment to check the weights during the researcher's absence, how they judged the weights upon the researcher's suggestion, and whether their judgments were related to the executive function and theory of mind were examined.

Results: Following the researcher's counter-intuitive information, the 3-year-olds were more likely to judge that the smallest one might be the heaviest. Further, spontaneous experiments during the researcher's absence were conducted only among a small number of children aged 4-years and up. There were no more differences in judgments of weight among age groups of children when it came to checking the actual weights of the dolls upon the researcher's suggestion. Additionally, children with better inhibitory and shifting ability tended to judge the heaviest doll based on their own intuition. A multiple regression analysis, controlling for relevant variables showed that only shifting ability predicted the children's judgments based on their intuition before the suggested experiment.

Conclusion: With age, young children may come to judge a physical situation based on their own clear intuition, rather than merely following another's counter-intuitive information. This tendency appears to be related to the executive function, especially shifting ability.

Keywords: counter-intuitive information, rational judgment, experiment, executive function

\section{Introduction}

유아들은 본인의 직접적 경험이나 환경과의 상호작용을 통 해 세상에 대한 지식을 구성해 나가기도 하지만(Bruner, 1973;

Corresponding Author: Jeein Jeong, Assistant Professor, Department of Child Development and Family Studies, Pusan National University \& Adjunct Researcher, Research Institute of Human Ecology, Pusan National University, 2, Busandaehak-ro 630beon-gil, Geumjeong-gu, Busan, Korea E-mail: jeongjee98@gmail.com
Piaget, 1930), 타인이 주는 정보나 다른 사람과의 상호작용 에서 얻어지는 지식 역시 학습에 있어 중요한 원천이 된다 (Gelman, 2009; Vygotsky, 1978). 학습을 둘러싼 이 두 가지 관 점 모두 풍부한 증거를 보여주고 있는 가운데, 한 가지 흥미로

(C)The Korean Association of Child Studies

This is an Open Access article distributed under the terms of the Creative Commons Attribution Non-Commercial License (http:// creativecommons.org/licenses/by-nc/4.0) which permits unrestricted noncommercial use, distribution, and reproduction in any medium, provided the original work is properly cited. 
운 질문은 타인이 주는 정보가 유아가 직접적으로 경험하는 물리적 세계와 일치하지 않을 때 유아들이 어떻게 판단해 나 가는지와 관련한 부분일 것이다. 이러한 상황에서 유아들은 본인이 지각하고 경험하는 대로 판단할 수도 있지만, 타인이 주는 정보에 손쉽게 따라갈 수도 있다. 아니면 상황을 좀 더 파 악하기 위해 실험하거나 탐색해 보려는 모습을 보일 수도 있 다. 본 연구에서는 타인이 주는 정보가 유아의 직관에 일치하 지 않는 상황에서 유아들이 어떻게 판단을 하게 되는지 살펴 보고, 이러한 판단에 영향을 미칠 수 있는 인지적 요인들에 대 해 살펴보고자 한다.

사실 최근의 연구들은 유아들에게 있어 타인이 주는 정보 를 비판적으로 바라보는 것이 쉽지 않을 수 있으며, 연령이 어 릴수록 타인이 주는 정보를 편향적으로 신뢰하는 경향이 높다 는 것을 보여주었다(Birch, Vauthier, \& Bloom, 2008; Clemént, Koenig, \& Harris, 2004; Jaswal et al., 2014; Jaswal \& Malone, 2007; Jaswal \& Neely, 2006; Ko \& Choi, 2011, 2013). 특히 만 2, 3 세의 어린 유아들은 타인이 제공하는 정보를 강하게 신뢰하 는 경향이 있어, 다른 사람이 유아의 이전 경험이나 지식에 반 하는 정보를 제공하더라도 반복적으로 그 정보를 신뢰하는 경 향이 있는 것으로 나타났다(Jaswal, Croft, Setia, \& Cole, 2010; Mascaro \& Sperber, 2009). 예를 들어, 만 3세 유아들은 인형이 이야기해 주는 정보를 듣고 어떤 상자 안에 물건이 들어있는 지 찾아야 하는 상황에서 인형이 총 여섯 번에 걸쳐 틀린 정보 를 주었음에도 인형이 말해주는 상자에서 물건을 찾으려고 하 는 경향을 보였다. 유아들은 만 4세가 되어서야 인형이 틀린 정보를 제공한다는 것을 몇 차례 경험한 후 인형이 주는 정보 에 따라가지 않는 모습을 보였다(Mascaro \& Sperber, 2009).

이러한 경향은 한국 유아들에게서도 유사하게 나타났는데, 만 4세 유아들은 1-2회의 관찰 후 성인이 틀린 정보를 주고 있 다는 것을 파악한 이후부터는 그 사람이 주는 정보를 더 이상 신뢰하지 않았던 반면, 만 3세 유아들은 계속해서 틀린 정보 를 주었던 성인의 정보에 따라가는 모습을 보였다(Chung \& Choi, 2013; Ko \& Choi, 2011). 또한, 만 4세 유아들은 놀이 진 행자의 정직성에 대한 특질이 변화하는지의 여부에 따라(예: 정직하던 사람이 부정직해졌는지) 그 사람이 주는 정보를 다 르게 수용하였던 반면, 만 3세 유아들은 변화에 대해 고려하지 않고 놀이 진행자를 계속해서 따라가는 모습을 보이기도 하 였다(Ko \& Choi, 2013). 이와 유사하게, 만 4세 이상의 유아들 은 이전에 항상 부정확한 정보를 주었던 성인보다는 항상 정 확했던 또래가 주는 정보를 더 신뢰하였던 반면, 만 3세 유아 들은 이러한 상황에서 뚜렷한 경향을 보이지 않았다(S. Jeong
\& Choi, 2017; J. Jeong, 2018). 따라서 어린 유아들일수록 성인 이 주는 정보에 대해 편향적으로 신뢰하는 경향이 높을 수 있 으며, 연령이 높아질수록 정보를 비판적으로 수용하는 경향이 나타나는 것으로 볼 수 있다.

그런데 이렇게 타인이 주는 정보를 비판적으로 수용하려는 경향은 직접적인 경험을 통해 상황을 파악하고자 하는 실험적 태도의 발현과 관련이 있을 수 있다(Ronfard, Chen, \& Harris, 2018). 유아들은 본인의 직관에 반하는 정보를 접하거나 정 황이 모호한 상황에서 실험하고 탐구하려는 태도를 더 자 주 보이는 것으로 나타났다(Cook, Goodman, \& Schulz, 2011; Legare, 2012; Legare, Gelman, \& Wellman, 2010). 예를 들어, 만 4-9세 아동들은 큰 물건보다 작은 물건의 그림자가 더 크게 나 타나는 상황에서, 이러한 정황을 파악하기 위한 탐구 행동을 더 많이 보이는 것으로 나타났다(van Schijndel, Visser, van Bers, \& Raijmakers, 2015). 즉, 그림자의 크기가 물건의 실제 크기에 비례한다는 유아들의 직관 또는 기존 지식에 위배 되는 상황 이 발생하자, 이러한 상황을 이해하기 위해 더 많은 탐구 행동 이 나타났던 것이다.

이와 유사한 맥락에서, Ronfard 등(2018)은 연구자가 모양 은 동일하지만 크기가 다른 다섯 개의 러시안 인형 중, 가장 작 은 인형이 가장 무겁다는 직관에 위배되는 정보를 줄 때, 중국 아동들이 무게를 확인해보려는 실험적 태도를 보이는지에 대 해 살펴본 바 있다(실제로는 직관에 일치하게 가장 큰 인형이 가장 무거운 상황이었음). 그 결과, 만 3-9세 아동의 상당수가 성인 연구자가 말해준 대로 가장 작은 인형이 가장 무거울 것 이라고 예측하는 경향을 보였다. 그러나 연구자가 잠시 자리 를 비운 사이, 일부 유아들은 인형을 직접 들어보며 어떤 인형 이 가장 무거운지 확인해보는 모습을 보였는데, 이러한 실험 적 경향은 3-6세 유아들보다는 7-9세 아동들에게서 더 많이 나 타났다. 이러한 결과는 성인이 직관에 반하는 정보를 주는 상 황에서 대체로 성인이 주는 정보에 따라가기는 하나, 연령이 증가하면서 상황의 진위를 판단하기 위한 실험적 태도가 증가 할 수 있음을 보여준다.

그러나 Ronfard 등(2018)의 연구는 중국에 거주하는 중국 아동들을 대상으로 이루어졌으며, 국내에서는 타인이 직관에 반하는 정보를 줄 때 유아들이 어떻게 판단을 하는지, 실험적 태도를 보이는지에 대해 다룬 연구가 부족한 실정이다. 또한 Ronfard 등(2018)의 연구에서는 유아들이 연구자가 부재할 때 자발적인 실험적 태도를 보이는지의 여부만을 살펴보았기 때 문에 자발적으로 실험을 해보았던 유아들만이 정보의 진위를 파악할 수 있는 기회를 가질 수 있었다. 만약 모든 유아에게 무 
게를 확인할 수 있는 기회가 주어진다면 본인의 직접적인 경 험에 비추어 가장 큰 인형이 가장 무겁다고 파악하게 되는지, 또는 여전히 성인이 말했던 정보에 따라가는지에 대한 부분을 추가적으로 살펴볼 수 있을 것이다.

더불어, 직관에 반하는 정보를 듣게 되었을 때 유아들이 내 리는 판단에 어떠한 인지적 능력이 영향을 미칠 수 있는지에 대해서도 연구가 부족한 실정이다. 즉, 본인의 직관에 기반을 두고 판단하는지, 또는 상대방이 주는 정보에 따라가는지에 대한 경향성이 어떠한 인지적 능력과 관련이 있는지에 대해 살펴볼 필요가 있다. 이에 대해 직접적으로 다룬 연구는 부족 하나, 몇 연구들은 타인이 주는 정보에 대해 비판적으로 판단 하는 능력과 실행기능의 관련성에 대해 이론적으로 제시하거 나(Ko \& Choi, 2011, 2013), 실증적으로 살펴본 바 있다(Jaswal et al., 2014; Lucas, Lewis, Pala, Wong, \& Berridge, 2013). 예를 들 어, Jaswal 등(2014)은 Gilbert, Krull와 Malone (1990)의 연구 를 참고하여, 틀린 정보를 반복해서 주었던 사람의 정보에 따 라가는 경향이 인지적 억제 부족과 관련이 있는지에 대해 살 펴본 바 있다. Gilbert 등(1990)의 연구에서 참여자들은 정보를 제공 받은 이후 이 정보가 사실인지 거짓인지 알게 되었으며, 그 후 인지적 부하가 있는 상황에서(문제를 푸는 동시에 소리 가 나면 버튼을 눌러야 함) 제공 받은 정보가 사실인지 거짓인 지 판단해야 하는 과업에 참여하였다. 그 결과, 거짓으로 판명 된 정보의 진위를 가려야 하는 상황에서 오답이 더 많이 나왔 고, Gilbert 등(1990)은 사람은 기본적으로는 다른 사람이 주는 정보를 자연스럽게 받아들이기 때문에, 그 후 그 정보가 거짓 임이 판명되어 거부해야 하는 상황에서는 인지적 노력이 더 많이 필요하여 인지적 부하가 있는 상황에서 오답이 많이 생 긴다고 설명하였다.

이러한 설명에 기반을 두고, Jaswal 등(2014)은 만 2-3세 유 아들이 과자가 떨어진 위치에 대해 틀린 정보를 반복적으로 주었던 성인의 정보에 따라가는지 살펴보고, 이러한 경향이 인지적 억제 능력의 부족과 관련이 있는지 검증하였다. 그 결 과, 2-3세 유아들의 판단은 인지적 억제 능력과 직접적인 상관 이 없었으나, 여섯 번 중 세 번 이상 성인이 주는 정보에 따라 갔던 유아들은 그렇지 않았던 유아들과는 달리, 인지적 억제 를 요구하지 않는 과업보다 요구하는 과업에서 어려움을 더 느끼는 것으로 나타났다.

그러나 사실상 Jaswal 등(2014)의 연구는 유아의 판단과 인 지적 억제 간의 관련성을 간접적으로 지지할 수 있는 결과만 을 제시하였기 때문에, 목표를 이루기 위해 자동화된 인지적 경향이나 반응에 저항하는데 필요한 인지적 억제 능력(Moore,
Barresi, \& Tohompson, 2001)이 성인의 정보에 대한 신뢰 편 향성 극복과 관련이 있는지에 대해서는 좀 더 검증이 필요하 다. 즉, Gilbert 등(1990)이 제시한 바와 같이 사람이 기본적으 로 타인이 주는 정보를 수용하는 경향이 있다면, 이러한 경향 을 극복하기 위해 인지적 억제 능력이 필요한지에 대해 살펴 볼 필요가 있다. 또한 Jaswal 등(2014)의 연구는 2-3세 유아들만 을 대상으로 이루어졌기 때문에, 인지적 억제 능력이 질적으 로 성장하는 만 3 세 이상의 유아들에게서는 어떠한 결과가 나 타날 것인지 알기 어렵다. 따라서 좀 더 높은 연령의 유아들을 포함하여 살펴본다면, 인지적 억제 능력이 직관에 반하는 정 보를 들었을 때 유아들이 내리는 판단과 관련이 있는지에 대 해 살펴볼 수 있는 기회가 될 것이다.

더불어, Jaswal 등(2014)은 실행기능 중에서도 인지적 억제 의 영향력만을 살펴보았으나, 인지적 전환 능력 역시 유아들의 판단과 관련이 있는지 살펴볼 필요가 있다. 인지적 전환은 인 지적 유연성이라고 불리기도 하는데, 목표 달성을 위해 전략이 나 생각의 방향을 유연하게 전환하는 융통적인 능력을 뜻한다 (Dennis \& Vander Wal, 2010). 인지적 억제는 유아기에 큰 폭으 로 증가하고 그 이후에는 증가 폭이 크지 않다고 알려진 것에 비해, 인지적 전환은 유아기와 그 이후에도 서서히 증가하는 것으로 알려져 있다(Best \& Miller, 2010). 다중 정보 속에서 합 리적인 판단을 내려야 하는 상황을 떠올려 본다면, 정보의 진 위나 타당성을 견주기 위해 정보나 생각을 자유롭게 오가며 융 통적으로 사고하는 능력이 필요할 수 있다. 따라서 인지적 억 제와 함께, 인지적 전환능력에 대해서도 살펴본다면, 실행기능 중에서도 어떠한 인지적 능력이 유아들의 판단 과정에 연루될 수 있는지에 대한 추가적 정보를 제공할 수 있을 것이다.

더불어 마음이론 역시, 타인이 주는 정보의 신뢰성 또는 정 확성을 판단하기 위해 필요한 부분이 될 수 있다(Jaswal et al., 2014, Vanderbilt, Liu, \& Heyman, 2011). 마음이론이란 자신과 타인의 믿음, 바람, 의도, 지각, 정서와 같은 정신적 상태에 대 해 이해하고, 이러한 정신 세계에 기반을 두고 사람의 행동을 이해하는 능력을 말한다(Wellman \& Liu, 2004). 다른 사람이 주 는 정보에 대해 객관적으로 판단하기 위해서는, 사람의 의도나 지식, 상황 등에 따라 그 사람이 주는 정보의 신뢰성이 달라질 것이라고 판단할 수 있어야 할 것이다. Jaswal 등(2014)은 앞서 설명한 연구를 통해 인지적 억제와 함께 마음이론이 2-3세 유 아들이 과자의 위치에 대해 판단하는 경향과 관련이 있는지 살 펴보았고, 그 결과 유의한 관련성이 없는 것으로 나타났다. 그 러나 Jaswal 등(2014)의 연구에서 사용된 Wellman과 Liu (2004) 의 마음이론 과업은 연구자들이 인정한 바와 같이 2-3세 유아 
들이 수행하기에 다소 난이도가 높았기 때문에 해당 유아들의 마음에 대한 이해를 민감하게 측정하지 못했을 가능성이 있다. 또한 타인이 주는 정보의 진위를 판단하는 데에는 거짓말에 대 한 이해가 관련이 있을 수 있기 때문에, 거짓말에 대한 이해를 포함하여 보다 폭넓게 마음이론을 측정할 필요도 있다.

이에, 본 연구에서는 Ronfard 등(2018)이 사용한 러시안 인 형 과업을 참고하여, 연구자가 유아의 직관에 위배되는 정보를 주는 상황에서 유아가 어떻게 판단을 내리는지, 연구자의 부재 시 자발적 실험 경향성이 나타나는지 살펴보고, 모든 유아들에 게 무게를 확인할 수 있는 기회를 준 후에는 인형의 무게에 대 해 어떻게 판단하는지에 대해 살펴보고자 한다. 또한 유아의 판단과 실험 경향성에 유아의 인지적 억제와 전환 능력, 그리 고 마음이론이 어떤 관련이 있는지에 대해 살펴보고자 한다.

\section{연구문제 1}

타인이 유아의 직관에 반하는 정보를 주는 상황에서 유아들 이 내리는 판단에는 연령에 따른 차이가 있는가?

\section{연구문제 2}

유아들이 자발적으로 실험을 하는지의 여부에는 연령에 따른 차이가 있는가?

\section{연구문제 3}

연구자의 권유로 실험을 한 후 유아들이 내리는 판단에는 연 령에 따른 차이가 있는가?

\section{연구문제 4}

유아의 연령, 인지적 억제, 인지적 전환, 마음이론, 유아들이 내리는 판단에는 어떤 관련이 있는가?

\section{연구문제 5}

유아의 인지적 억제, 인지적 전환, 마음이론은 유아들이 내리 는 판단에 영향을 미치는가?

\section{Methods}

\section{연구대상}

본 연구는 J시에 소재한 어린이집에 재원하고 있는 만 $3,4,5$, 6 세 유아 92명을 대상으로 진행되었다. 최종적으로 만 3세 유
아 22명(남아 13 명, 여아 9명, $M=3.64, S D=.34$ ), 만 4세 유 아 24 명 (남아 12 명, 여아 12 명, $M=4.64, S D=.36$ ), 만 5세 유 아 21명(남아 12 명, 여아 9명, $M=5.62, S D=.35$ ), 만 6세 유아 25 명(남아 16 명, 여아 9명, $M=6.4, S D=.17$ )이 참여하였다. G-Power 3.1.9를 사용하여 카이제곱 검정을 위한 집단 크기를 산정하였을 때(유의 수준 .05, 파워 .80), 총 88명 이상의 유아 가 필요한 것으로 나타나 각 집단별로 22 명 정도가 필요하였 기 때문에 모집된 유아의 수는 적절한 것으로 판단되었다.

참여한 유아 가정의 사회경제학적 수준에 대한 자료로 가 정의 소득 수준에 대해 살펴본 결과, 월 소득 200-300만 원이 7명(7.6\%), 300-400만 원이 8명(8.7\%), 400-500만 원이 14명 (15.2\%), 500-600만 원이 21명(22.8\%), 600만 원 이상이 42명 $(45.7 \%)$ 인 것으로 나타났다.

\section{연구도구}

\section{직관에 반하는 정보가 주어질 때 유아의 판단 과업}

연구자가 유아의 직관에 반하는 정보를 주는 상황에서 유아들 이 내리는 판단에 대해 살펴보기 위해, 본 연구에서는 Ronfard 등(2018)이 사용한 도구를 본 연구의 목적에 맞도록 변형하여 사용하였다. Ronfard 등(2018)의 연구에서와 동일하게 모양 은 같지만 크기가 다른 다섯 개의 러시안 인형을 사용하였으 며, 가장 큰 인형에서 가장 작은 인형 순서로 $12 \mathrm{~cm}(107 \mathrm{~g}), 8 \mathrm{~cm}$ $(34 \mathrm{~g}), 6 \mathrm{~cm}(12 \mathrm{~g}), 4 \mathrm{~cm}(5 \mathrm{~g}), 2 \mathrm{~cm}(2 \mathrm{~g})$ 였다. 실험 절차는 Ronfard 등(2018)과 유사하였으나, Ronfard 등(2018)의 연구에서는 연 구자가 유아의 직관에 일치하는 정보를 주는 조건과 직관에 일치하지 않는 정보를 주는 조건 모두를 살펴보았던 반면, 본 연구에서는 직관에 반하는 정보를 주는 상황에 대해서만 살펴 보았다. 또한 모든 유아들에게 인형의 무게를 직접 확인해보 는 기회를 제공하기 위해, 연구자의 권유로 무게를 확인해보 도록 하는 절차를 추가하였다. 유아가 과업에 참여하는 모습 은 비디오 카메라를 통해 녹화되었다.

먼저 연구자는 유아와 친숙해진 후에 러시안 인형 다섯 개 를 소개하며 어떤 인형이 가장 무거울 것이라고 생각하는지 질문하였다. 그 후 유아들의 응답을 들은 후 "(가장 작은 인형 을 가리키며)사실 이 인형이 제일 무거워.”라고 직관에 위배되 는 정보를 주었다. 이렇듯 직관에 위배되는 정보를 들은 후 유 아들이 무게에 대해 어떻게 판단하는지 보기 위해 "다시 한 번 물어볼게. 어떤 인형이 가장 무거울까?”라고 질문을 하였다. 
유아의 응답을 들은 후에는 "아.. 맞다. 나는 지금 옆 방에 전화를 받으러 잠깐 나가봐야 하거든. 잠깐 나갔다 돌아올게." 라고 이야기하며 유아를 조용한 방 안에 혼자 두었다. 연구자 는 약 1 분 후에 돌아왔으며 연구자가 부재할 때 유아들이 인형 을 들어보며 무게를 확인하기 위한 자발적인 실험을 해보는지 에 대해서는 미리 설치해 둔 카메라를 통해 녹화하였다.

그 후, 돌아온 연구자는 “잘 기다리고 있었어? 여기 인형들 중에서 어떤 인형이 제일 무겁지?”라고 다시 질문을 하였다. 그 후, 연구자는 모든 유아들에게 인형의 무게를 확인해 볼 수 있는 기회를 주기 위해 “그럼 여기 있는 인형을 한 번 들어볼 래?”라고 권유하며 유아들이 모든 인형을 적어도 한 번씩은 다 들어볼 수 있도록 권유된 실험 기회를 제공하였다.

권유된 실험 직후 연구자는 "어떤 인형이 여기서 제일 무거 워?”라고 직접적으로 질문하였다. 그 후, 좀 더 실제적인 맥락 에서 가장 무거운 인형을 찾아야 하는 상황을 제공하기 위해 사람 모양 인형과 가벼운 종이 뭉치를 꺼내면서 “이 친구(사람 모양 인형)가 이 종이가 날아가지 않도록 제일 무거운 인형으 로 종이를 눌러놓으려고 하거든? 제일 무거운 인형을 종이 위 에 올려놓아야 하는데 어떤 인형을 올려놓으면 좋을까?”라고 질문을 하였고, 이로써 유아의 판단 과업은 마무리가 되었다.

연구자가 가장 무거운 러시안 인형이 무엇일지에 대해 질문 하였을 때, 매우 소수의 유아들은 중간 크기의 인형을 고르기 도 하였으나, 대다수의 유아들은 가장 큰 인형이나 가장 작은 인형 둘 중 하나를 골랐다. 따라서 분석을 용이하게 하기 위해 유아가 직관에 일치하게 가장 큰 인형이 가장 무겁다고 응답 한 경우에는 2 , 가장 큰 인형이 아닌 다른 인형이 가장 무겁다 고 응답하면 1 로 코딩하였다. 또한 연구자의 부재 시 유아가 혼 자 남겨졌을 때 인형을 들어보며 무게를 확인해보는지에 대해 서는 비디오에 촬영된 모습을 토대로 코딩하였으며, 인형 다섯 개 중 하나라도 들어보았으면 2, 아예 인형을 들어보지 않거나 그냥 손가락으로 건드려보기만 한 경우(예: 들어보지 않고 인 형 머리 부분을 손가락으로 건드려 봄)에는 1 로 코딩하였다. 비 디오 코딩은 연구자 1 인과 자료 수집에 참여하지 않은 연구 보 조원 한 명이 각각 모든 비디오 자료에 대해 코딩을 하였고, 모 든 비디오 장면에 대해 코딩이 일치하는 것으로 나타났다.

\section{실행기능}

인지적 억제 유아의 인지적 억제를 측정하기 위해 Gerstadt, Hong과 Diamond (1994)가 고안한 낮-밤(Day-Night) 과제를 수정하여 사용하였다. 과업에서 유아들은 보이는 그림에 반대
로 대답을 해야 했으며, 따라서 달 그림을 보면 ‘해’라고 말하 고, 해 그림을 보면 '달'이라고 응답해야 했다. 본 검사에서는 총 16장의 카드(해 그림 8장, 달 그림 8장)가 사용되었으며, 연 구자는 과업의 규칙을 잘 이해하였는지 사전 연습을 통해 확 인하였다. 정확한 과제 수행을 한 경우에는 1점, 틀리면 0점을 부여하여 총점의 범위는 0-16점이 되었다.

인지적 전환 유아의 인지적 전환을 측정하기 위해 Zelazo (2006)의 카드 분류 과제를 사용하였다. 이 과제에서는 이전 상황에서 적용되던 규칙에서 벗어나 전략이나 사고 과정, 행 동 등을 바꾸는 유연한 사고를 필요로 한다. 검사는 총 3 단계 로 진행되었고 첫 번째는 '색’ 범주로 카드를 분류하게 하고, 두 번째는 '모양' 범주로, 세 번째는 테두리 규칙을 추가하여 테두리가 있으면 색깔범주에 따라, 테두리가 없으면 모양 범 주에 따라 카드를 분류하게 하였다. 각 게임은 '색깔 게임', '모 양 게임', '테두리 게임'이라 명명하였고, 순서대로 게임을 진 행하였다. 총점의 범위는 색깔 게임 0-6점, 모양 게임 0-6점, 테 두리 게임 0-12점이 되어서 총 24점이 되었다.

$$
\text { 마음이론 }
$$

유아들의 마음이론은 Wellman과 Liu (2004)가 사용한 다섯 개의 과제와 유아들의 거짓말에 대한 이해를 측정하기 위해 Happé (1994)와 Bussey (1999)가 고안한 이야기를 Gwon과 Lee (2012)가 수정 보완한 이야기 중 두 가지를 사용하여 측정하 였다. Wellman과 Liu (2004)가 사용한 과업 중에서는 유아들 이 이야기 속 주인공이 주인공의 간식에 대한 선호(예: 피자 대신 옥수수를 좋아함)에 따라 행동할 것이라는 것을 이해하 는지에 대해 측정하는 다양한 욕망에 대한 이해 과업(diverse desire), 이야기 속의 주인공이 본인의 믿음에 근거하여 행동 할 것이라는 것을 이해하는지에 대해 묻는 다양한 믿음 이해 과업(diverse beliefs), 상자 안을 보지 않은 사람은 상자 안의 내 용물을 모른다는 것을 이해하는지 묻는 지식 접근에 대한 이 해 과업(knowledge access), 상대방이 실제와 다른 틀린 믿음 을 가지고 있을 수 있다는 것에 대해 이해하는지 묻는 틀린 믿 음 이해 과업(false belief), 본인의 믿음에 따른 정서가 결정된 다는 것을 이해하는지 측정하는 믿음에 따른 정서 과업(beliefemotion)을 사용하였다. 또한 거짓말에 대한 이해 과업에서는 유아들에게 두 가지 이야기를 들려준 후 이야기에서 주인공이 한 말이 거짓말인지 사실인지에 대해 구분하는지 질문하였다. 마음이론과 관련하여 총 일곱 가지 이야기를 들려주었기 때문 
에 마음이론 점수는 0-7점 사이에 분포하였다.

\section{연구절차}

연구 시작에 앞서 부산대학교 생명윤리위원회의 IRB 승인을 받았으며, 본 연구를 실시하기 전 예비조사를 통해 각 과업이 유아들의 수준에 적합한지, 수정해야 할 부분이 있는지 확인 하였다. 최종 연구 절차를 확정한 후, 어린이집에 연구 설명문 을 배부한 후, 학부모가 연구 참여에 동의한 유아들에 한해 연 구가 진행되었으며, 자료수집은 2020년 8월부터 9월 사이에 진행되었다.

모든 측정은 두 차례의 연구자와 유아 간의 일대일 면담을 통해 이루어졌으며 각 면담은 어린이집 내의 조용한 공간에서 20 분 이내로 진행되었다. 유아에게는 직관에 반하는 정보가 주 어질 때의 유아의 판단 과업, 실행기능 과업(인지적 억제, 인지 적 전환), 마음이론 과업이 주어졌으며, 세 가지 과업이 주어지 는 순서는 유아 간 역균형화 되었고 실행기능과 마음이론 과업 내에서 세부 과업이 주어지는 순서는 무작위로 결정되었다.

\section{자료분석}

자료는 SPSS 22.0 (IBM Co., Armonk, NY)통계 프로그램을 통 해 분석하였다. 연령별 판단의 경향이나 자발적 실험을 해보았 는지의 여부는 카이제곱검정과 피셔의 정확검정을 통해 살펴 보았으며, 카이제곱검정 결과가 유의한 경우에는 사후검증을 위한 카이제곱검정을 추가로 실시하여 어떤 연령에서 차이가 발생하였는지 살펴보았다. 권유된 실험 직후 인형의 무게에 대 한 유아의 판단과 종이를 누르기 위한 인형을 고르는 판단에서 의 차이는 McNemar Test를 통해 살펴보았으며, 실행기능과 마 음이론 점수에서의 연령별 차이는 ANOVA와 Scheffé Test를 통 해 살펴보았다. 유아의 판단에 영향을 주는 변수가 있는지 종 합적으로 확인하기 위해서는 중다회귀 분석을 실시하였다.

\section{Results}

\section{직관에 반하는 정보가 주어지는 상황에서 유아의 판단}

가장 작은 인형이 가장 무겁다는 직관에 반하는 정보를 제공 하기 전에는 만 3 세 한 명, 만 6 세 한 명을 제외한 모든 유아들
이 직관에 부합하게 가장 큰 인형이 가장 무거울 것이라고 판 단하는 것으로 나타났다. 연구자가 가장 작은 인형이 가장 무 겁다고 이야기를 한 후에는 “어떤 인형이 가장 무거울까?”라 는 질문에 만 3 세의 대부분인 19 명 $(86.4 \%)$, 만 4 세 중 14 명 (58.3\%), 만 5세 중 14 명(66.7\%), 만 6세의 12 명(48\%)이 가장 큰 인형이 아닌 다른 인형이 가장 무겁다고 응답하는 것으로 나타났다(Table 1-1 참고).

카이제곱검정 결과, 연구자의 정보를 들은 후 유아들이 내 리는 판단에는 연령에 따른 차이가 있는 것으로 나타났으며 $\left(\chi^{2}=7.97 p<.05\right)$, 구체적으로 어떤 연령에서 기대되는 응답 양상과 다른 경향이 나타났는지 살펴보기 위해 각 Cell의 조정 된 잔차(adjusted residual)의 카이제곱 값을 수정된 유의 수준인 0.0125 (Bonferroni corrected $p$ value)와 비교하였다. 그 결과, 만 3 세의 응답이 기대되는 수준과 달랐고, 구체적으로 만 3 세 유 아의 경우 가장 무거운 인형으로 가장 큰 인형을 고르는 경향 이 적었던 반면 $\left(\chi^{2}=6.22, p<.05\right)$, 가장 큰 인형을 제외한 나머 지 인형들을 고르는 경향은 높은 것으로 $\left(\chi^{2}=6.20, p<.05\right)$ 나 타났다. 이는 연구자로부터 직관에 반하는 정보를 들었을 때, 만 3세 유아들이 본인의 초기 판단을 바꾸어 연구자가 준 정보 에 따라가는 경향이 높음을 의미한다.

\section{유아의 자발적 실험 여부와 그 이후 유아의 판단}

연구자가 자리를 비운 사이 유아가 자발적으로 인형을 들어보 는 실험을 해보았는지 살펴본 결과는 Table 2 와 같다. 적어도 한 개 이상의 인형을 들어보았는지, 또는 아예 건드리지 않거 나 단순히 인형을 손가락으로 건드려보기만 하였는지(인형의 머리 부분을 손가락으로 톡 건드림)에 따라 두 범주로 나누었 으며, 기대되는 빈도가 5 보다 작은 Cello $25 \%$ 이상 나왔기 때 문에 피셔의 정확검정을 통해 연령에 따라 자발적 실험의 빈 도가 다르게 나왔는지 검증한 결과, 유의한 수준에 가깝게 연 령에 따른 차이가 있는 것으로 나타났다 $(p=.05)$. 이것은 만 3 세에서는 자발적 실험을 해 본 유아가 전혀 없었던 반면, 더 높 은 연령대에서는 소수의 유아가 자발적 실험을 하였던 결과를 반영한다고 볼 수 있다.

또한 연구자의 부재 시 실험을 자발적으로 해 보았는지의 여부와 관련 없이 연구자가 유아에게 돌아온 후 어떤 인형이 가장 무거운 것 같은지 다시 물어보았으며, 이 때 유아의 판단 에 대해 살펴본 결과는 Table 1-2와 같다. 만 3세의 대부분인 20 명(90.9\%), 만 4세 중 15명(62.5\%), 만 5세 중 13명(61.9\%), 만 6 세의 11 명(44\%)이 가장 큰 인형이 아닌 다른 인형이 가장 무 
Table 1

Judgments before Recommended Experiment

1-1. Children's judgments of heaviest doll after hearing counter-intuitive information

Frequency

\begin{tabular}{lcccccc} 
& \multicolumn{3}{c}{$(\%)$} & $\chi^{2}$ \\
\hline & 3 year & 4 year & 5 year & 6 year & Total children \\
\hline The biggest doll & 3 & 10 & 7 & 13 & 33 & $(35.9 \%)$ \\
Non biggest doll & $(13.6 \%)$ & $(41.7 \%)$ & $(33.3 \%)$ & $(52 \%)$ & 59 & $7.97^{*}$ \\
& 19 & 14 & 14 & $(48 \%)$ & $(64.1 \%)$ & \\
\hline
\end{tabular}

1-2. Children's judgments of heaviest doll after the researcher's comeback

Frequency

$(\%)$

\begin{tabular}{|c|c|c|c|c|c|c|}
\hline & & & $(\%)$ & & & $\chi^{2}$ \\
\hline The biggest doll & 2 & 9 & 8 & 33 & 33 & \multirow{4}{*}{$11.34^{*}$} \\
\hline \multirow{3}{*}{ Non biggest doll } & $(9.1 \%)$ & $(37.5 \%)$ & $(38.1)$ & $(35.9 \%)$ & $(35.9 \%)$ & \\
\hline & 20 & 15 & 13 & 11 & 59 & \\
\hline & $(90.9 \%)$ & $(62.5 \%)$ & $(61.9 \%)$ & $(44 \%)$ & $(64.1 \%)$ & \\
\hline
\end{tabular}

Note. $N=92$.

${ }^{*} p<.05$.

Table 2

Children's Spontaneous Experiment

\begin{tabular}{|c|c|c|c|c|c|}
\hline & \multicolumn{4}{|c|}{$\begin{array}{c}\text { Frequency } \\
(\%)\end{array}$} & \multirow[t]{2}{*}{ Total children } \\
\hline & 3 year & 4 year & 5 year & 6 year & \\
\hline No experiment & $\begin{array}{c}22 \\
(100 \%)\end{array}$ & $\begin{array}{c}18 \\
(75 \%)\end{array}$ & $\begin{array}{c}16 \\
(76.2 \%)\end{array}$ & $\begin{array}{c}21 \\
(84 \%) \\
\end{array}$ & $\begin{array}{c}77 \\
(83.7 \%)\end{array}$ \\
\hline
\end{tabular}

Fisher's exact test $\mathrm{p}$ value 0.05

Note. $N=92$.

겁다고 응답하는 것으로 나타났으며, 카이제곱 검정 결과, 연 령에 따라 판단 경향이 다른 것으로 나타났다 $\left(\chi^{2}=11.34, p<\right.$ .05). 구체적으로 어떤 연령에서 기대되는 양상과 다른 경향이 나타났는지 살펴보기 위해 각 Cell의 조정된 잔차의 카이제곱 값을 수정된 유의수준인 0.0125 (Bonferroni corrected p value) 와 비교한 결과, 만 3 세의 경향성이 기대되는 값들과 다른 것 으로 나타났다. 즉, 만 3 세의 경우 가장 큰 인형이 가장 무겁다 고 응답하는 경향이 매우 낮고 $\left(\chi^{2}=9.00, p<.01\right)$, 가장 큰 인형 을 제외한 나머지 인형 중 하나가 가장 무겁다고 응답하는 경 향이 매우 높았다 $\left(\chi^{2}=9.00, p<.01\right)$. 따라서 앞선 분석에서와 유사하게, 만 3 세들은 연구자의 정보에 따라가는 경향이 다른 연령보다 높았다고 볼 수 있다.

이어서, 유아가 연구자가 돌아온 후에 인형의 무게에 대해 어떻게 판단하였는지와 무관하게 모든 유아들에게 무게를 확
인하는 실험을 해보도록 권유하였고, 유아들은 모든 인형을 적어도 각각 한 번씩은 들어볼 기회를 가질 수 있었다. 이렇게 연구자의 권유로 무게를 확인해보는 실험을 해본 후, 유아들 에게 어떤 인형이 가장 무겁다고 생각하는지 질문하였고, 그 에 대한 유아들의 응답은 Table 3-1과 같다. 권유된 실험 직후 에 만 3세 중 12 명(54.5\%), 만 4세 중 16명(66.7\%), 만 5세 중 18 명(85.7\%), 만 6세 중 15 명(60\%)이 가장 큰 인형이 가장 무 겁다고 응답하였으며, 카이제곱 검정 결과, 연령에 따라 판단 경향이 다르지 않은 것으로 나타났다 $\left(\chi^{2}=5.35, p>.05\right)$.

그 후 연구자는 친구(사람 모양 인형)가 종이가 날아가지 않도록 올려놓을 수 있는 가장 무거운 인형을 골라 달라고 요 청하였고, 이에 대한 유아들의 판단은 Table 3-2와 같다. 표에 서와 같이, 종이 받침으로 적절한 무거운 인형에 대해 만 3세 중 17 명(77.3\%), 만 4세 중 23명(95.8\%), 만 5세 중 17 명(81\%), 
Table 3

Judgments after Recommended Experiment

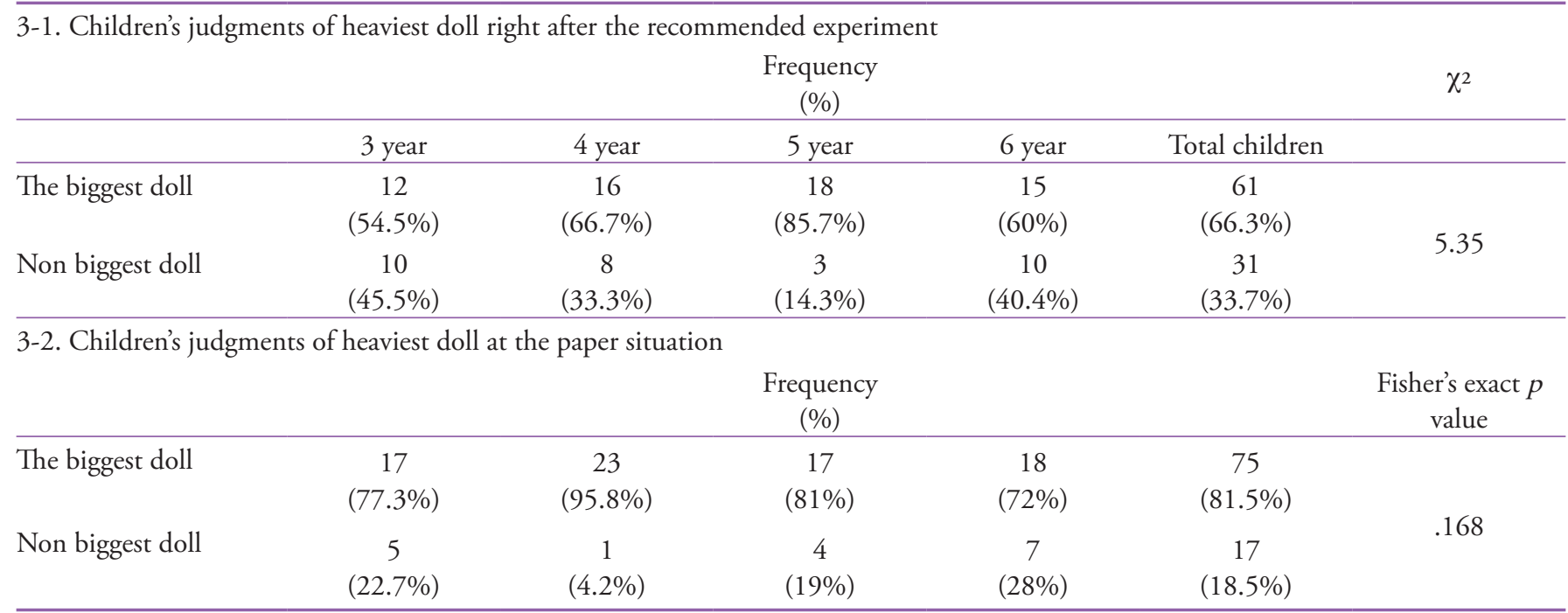

Note. $N=92$.

만 6세 중 18 명(72\%)이 가장 큰 인형을 고르는 것으로 나타났 다. 기대되는 빈도가 5 보다 작은 Cell이 $25 \%$ 이상인 관계로 피 셔의 정확검정 결과를 살펴본 결과, 연령에 따라 유아들의 판 단이 다르지 않은 것으로 나타났다 $(p=.168)$.

따라서 연구자의 권유로 인형을 들어보며 무게를 확인해 본 후에는 어떤 인형이 무거운지에 대한 판단에 있어 연령에 따른 차이가 없는 것으로 나타났다. 그러나 McNemar Test를 통해 연 구자의 권유로 인형의 무게를 확인한 직후 유아들이 내린 판단 과 종이를 눌러놓기 위해 가장 무거운 인형을 찾아야 했던 상황 에서 내린 판단 사이에 차이가 있는지 세부적으로 살펴본 결과, 종이를 눌러놓을 인형을 찾는 상황에서 가장 큰 인형을 고르는 유아들의 비율이 높아짐을 확인할 수 있었다 $(p=.001)$.

\section{유아의 연령, 인지적 억제, 인지적 전환, 마음이론, 무게에 대한 판단의 관계}

\section{유아의 인지적 억제, 인지적 전환, 마음이론}

유아의 연령별 인지적 억제, 인지적 전환 점수는 Table 4와 같 다. 연령별 차이를 살펴보기 위해 ANOVA를 통해 분석한 결 과, 인지적 억제 점수에서 연령에 따른 유의한 차이가 있는 것 으로 나타났고 $(F=10.01, p<.001)$, Scheffé 사후 분석 결과, 만 3 세보다는 만 5세, 만 6세의 점수가 각각 높았고, 만 4세보다 만 6세의 점수가 더 높은 것으로 나타났다. 인지적 전환에서도 연령에 따른 차이가 있었으며 $(F=7.44, p<.001)$, Scheffé 사후
분석 결과, 만 3세보다는 만 5세, 6세의 점수가 높았고, 만 4세 보다는 만 5세의 점수가 더 높은 것으로 나타났다.

유아의 연령별 마음이론 점수 역시 ANOVA를 통해 분석한 결과, 연령에 따라 마음이론 과업 점수가 달라지는 것으로 나 타났으며 $(F=7.66, p<.001)$, Scheffé 사후 분석 결과, 만 3세보 다는 만 5세, 6 세의 평균이 높았으며, 만 4세보다는 만 6세의 평균이 더 높은 것으로 나타났다(Table 4 참고).

유아의 연령, 인지적 억제, 인지적 전환, 마음이론, 무게에 대한 판단의 관계

연구자의 권유로 무게를 확인해보기 전후로 유아들의 무게에 대한 판단 양상이 달라졌으므로 권유된 실험 전에 두 차례에 걸 쳐 내린 판단과 권유된 실험 후에 두 차례에 걸쳐 내린 판단을 합산하여 ‘권유된 실험 전 판단' '권유된 실험 후 판단'으로 명명 하였다. 유아의 연령, 가정의 소득 수준, 실행기능, 마음이론, 유 아의 판단간의 상관관계를 살펴본 결과는 Table 5 와 같다.

상관관계 분석 결과 유아의 연령은 권유된 실험 전 판단 $(r$ $=.31, p<.01)$, 인지적 억제 $(r=.54, p<.001)$, 인지적 전환 $(r=$ $.40, p<.001)$, 마음이론 $(r=.50, p<.001)$ 과 정적 상관이 있었 으며, 가정의 소득 수준은 다른 변수들과 유의한 관련이 없는 것으로 나타났다. 권유된 실험 전 유아의 판단은 권유된 실험 후 판단 $(r=.24, p<.05)$, 인지적 억제 $(r=.26, p<.05)$, 인지적 전환 $(r=.35, p<.01)$ 과 정적 상관이 있는 것으로 나타났다. 연 령에 의한 효과를 통제한 편 상관관계 분석 결과, 권유된 실험 
Table 4

Children's Cognitive Inhibition, Cognitive Shifting, and Theory of Mind

\begin{tabular}{|c|c|c|c|c|c|c|c|}
\hline & & 3 year & 4 year & 5 year & 6 year & $F$ & Scheffé \\
\hline \multirow[t]{3}{*}{ Cognitive inhibition } & $M$ & 9.45 & 11.17 & 13.10 & 14.52 & \multirow{3}{*}{$10.01^{* * *}$} & $3<5$ \\
\hline & & & & & & & $3<6$ \\
\hline & $S D$ & 4.52 & 3.55 & 3.25 & 1.74 & & $4<6$ \\
\hline \multirow[t]{3}{*}{ Cognitive flexibility } & $M$ & 17.50 & 17.75 & 20.62 & 19.96 & \multirow{3}{*}{$7.44^{* * *}$} & $3<6$ \\
\hline & & & & & & & $3<5$ \\
\hline & $S D$ & 1.87 & 3.26 & 2.50 & 2.94 & & $4<5$ \\
\hline \multirow[t]{3}{*}{ Theory of mind } & $M$ & 4.00 & 4.38 & 5.48 & 5.64 & \multirow{3}{*}{$7.66^{* * *}$} & $3<5$ \\
\hline & & & & & & & $3<6$ \\
\hline & $S D$ & 1.63 & 1.74 & .87 & 1.15 & & $4<6$ \\
\hline
\end{tabular}

Note. $N=92$.

${ }^{* * *} p<.001$.

Table 5

The Correlations Among Age, Family Income, Judgments before the Recommended Experiment, Judgments after the Recommended Experiment, Cognitive Inhibition, Cognitive Flexibility, and Theory of Mind

\begin{tabular}{|c|c|c|c|c|c|c|c|}
\hline & 1 & 2 & 3 & 4 & 5 & 6 & 7 \\
\hline 1. Age & - & & & & & & \\
\hline 2. Family income & -.03 & - & & & & & \\
\hline 3. Total judgments before recommended experiment & $.31^{* *}$ & $\begin{array}{c}.13 \\
(.19)\end{array}$ & - & & & & \\
\hline 4. Total judgments after recommended experiment & -.05 & $\begin{array}{l}-.67 \\
(-.04)\end{array}$ & $\begin{array}{c}.24^{*} \\
\left(.27^{*}\right)\end{array}$ & - & & & \\
\hline 5. Cognitive inhibition & $.54^{* * *}$ & $\begin{array}{l}-.02 \\
(.07)\end{array}$ & $\begin{array}{l}.26^{*} \\
(.12)\end{array}$ & $\begin{array}{l}-.01 \\
(.02)\end{array}$ & - & & \\
\hline 6. Cognitive flexibility & $.40^{* * *}$ & $\begin{array}{l}.16 \\
(.19)\end{array}$ & $\begin{array}{c}.35^{* *} \\
\left(.26^{*}\right)\end{array}$ & $\begin{array}{l}.13 \\
(.16)\end{array}$ & $\begin{array}{c}.20 \\
(-.01)\end{array}$ & - & \\
\hline 7. Theory of mind & $.50^{* * *}$ & $\begin{array}{c}.12 \\
(.18)\end{array}$ & $\begin{array}{c}.13 \\
(-.03)\end{array}$ & $\begin{array}{l}-.044 \\
(-.02)\end{array}$ & $\begin{array}{l}.27^{* *} \\
(.01)\end{array}$ & $\begin{array}{l}.41^{* * *} \\
\left(.27^{*}\right)\end{array}$ & - \\
\hline
\end{tabular}

Note. $N=92$. Coeffiets in parentheses are age partialled correlation.

${ }^{*} p<.05 .{ }^{* *} p<.01 .{ }^{* * *} p<.001$.

전 판단은 권유된 실험 후 판단 $(r=.27, p<.05)$, 인지적 전환( $\mathrm{r}$ $=.26, \mathrm{p}<.05)$ 과 각각 정적 상관관계가 있는 것으로 나타났다.

\section{유아의 연령과 인지적 억제, 인지적 전환이 유아의 무게 판단에 미치는 영향}

위의 상관관계 분석 결과, 마음이론은 유아의 무게 판단과 유 의한 관련이 없었으며, 권유된 실험 전 판단은 유아의 인지적 억제, 인지적 전환과 관련이 있었던 반면, 권유된 실험 후 판
단은 인지적 억제, 인지적 전환과 관련이 없는 것으로 나타났 다. 따라서, 권유된 실험 전 판단에 영향을 미치는 요인들이 무 엇인지에 대해서만 중다회귀분석을 통해 살펴보았다. 예측 변 수들의 Variance Inflation Factor (VIF)는 1.17 1.52로 나타나 모 두 10보다 작았고, 공차 한계는 .657-.852로 모두 .1보다 커서 다중공선성에 문제가 없는 것으로 나타났다. 또한 연령, 인지 적 억제, 인지적 전환을 보기 위한 최종 모델에서의 DurbinWatson도 각각 1.68 로 나타나 정상분포곡선에 가깝고(2에 근 접) 0 또는 4 와 가깝지 않아서 잔차 간 상관관계가 적어 회귀 
Table 6

The Regression Results to Predict Children's Judgments before the Recommended Experiment

\begin{tabular}{|c|c|c|c|}
\hline \multirow{2}{*}{ Variables } & \multicolumn{3}{|c|}{ Children's judgments before recommended experiment } \\
\hline & $B$ & $S E$ & $\beta$ \\
\hline (constant) & .12 & .31 & \\
\hline Age & .05 & .05 & .12 \\
\hline Cognitive inhibition & .02 & .01 & .15 \\
\hline Cognitive flexibility & .04 & .02 & $.27^{* *}$ \\
\hline$F(p)$ & & $5.96^{* * *}$ & \\
\hline$R^{2}$ & & .169 & \\
\hline
\end{tabular}

Note. $N=92$.

${ }^{* *} p<.01 .{ }^{* * *} p<.001$.

분석에 문제가 없는 것으로 나타났다.

연령과 인지적 억제, 인지적 전환을 동시에 투입하여 이 변 수들이 권유된 실험 전 판단에 미치는 영향을 알아본 결과는 Table 6과 같다. 분석 결과, 인지적 전환만이 권유된 무게 측정 전 유아의 판단에 영향을 미치는 것으로 나타났으며 $(\beta=.27, p$ <.01), 이는 실제로 무게를 확인해보기 전에는 인지적 전환 능 력이 높을수록 연구자가 직관에 위배 되는 정보를 주었을 때 연구자가 주는 정보보다는 본인의 직관에 기반하여 판단을 내 리는 경향이 높다는 것을 보여준다.

\section{Discussion}

본 연구에서는 연구자가 유아의 직관에 반하는 정보를 주는 상황에서 만 3세에서 6세 유아들이 어떻게 판단을 내리는지, 상황을 판단하기 위해 실험적 태도를 보이는지 살펴보고, 이 러한 부분이 유아의 실행기능과 마음이론과 관련이 있는지에 대해 알아보았다. 크기가 다른 다섯 개의 인형 중에서 가장 작 은 인형이 가장 무겁다는 직관에 반하는 정보를 들었을 때, 만 3세 유아들은 더 높은 연령에 비해 연구자가 주는 정보에 따 라가는 경향이 높은 것으로 나타났다. 또한 연구자의 부재 동 안 인형의 무게를 확인해보는 실험적 태도는 만 4 세 이상의 유 아들에게서만 소수 나타났으며, 연구자의 권유로 인형의 실제 무게를 확인한 이후에는 인형의 무게에 대한 유아의 판단에서 연령에 따른 차이가 없는 것으로 나타났다. 더불어, 유아의 인 지적 전환은 다른 관련 변수들의 가능한 영향력을 감안한 후 에도 권유된 실험 전 유아의 판단을 유의하게 예측하는 것으 로 나타나, 인지적 전환 능력이 높을수록 직관에 반하는 정보 를 들었을 때, 이 정보에 따라가기보다는 본인의 직관에 기반
을 두고 판단하는 경향이 높은 것으로 나타났다.

연구자가 유아의 직관에 반하는 정보를 주는 상황에서 유 아들이 연구자가 주는 정보에 따라가는 경향은 연령에 따라 달 라지는 것으로 나타났다. 특히 다른 연령보다는 만 3세에서 연 구자가 주는 정보에 따라가는 경향이 높았다. 이와 같은 결과 는 연령이 낮을수록 성인의 말을 편향적으로 신뢰하는 경향이 높다는 것을 보여준 국내외의 이전 연구들과(Birch et al., 2008; Clemént et al., 2004; Harris \& Corriveau, 2014; Jaswal et al., 2014; Jaswal \& Neely, 2006; Ko \& Choi, 2011, 2013) 유사한 맥락에 있 다고 볼 수 있다. 예를 들어, 만 3 세 유아들은 4 세와는 달리 성 인이 물건이나 스티커의 위치를 반복해서 틀리게 이야기했던 경우에도 그 사람이 주는 정보를 계속해서 신뢰하는 경향을 보이는 것으로 나타났다(Jaswal et al., 2010; Ko \& Choi, 2011, 2013; Mascaro \& Sperber, 2009). 따라서 만 3세 이하의 유아들 은 성인이 주는 정보 자체를 신뢰하는 경향이 높다고 볼 수 있 으며, 성인이 주는 정보가 본인의 직관에 분명히 반하는 상황 에서도 이러한 경향성은 유지되는 것으로 볼 수 있다.

또한, 직관에 반하는 정보를 제공한 연구자가 자리를 비웠 을 때, 유아들이 인형의 무게를 확인하는 실험을 해보는지 살 펴본 결과, 전체 92 명의 유아 중 오직 15 명의 유아만이 연구자 가 없을 때 인형을 들어보는 실험을 해보는 것으로 나타났다. 자발적 실험을 하였던 유아의 수가 매우 소수였기 때문에, 유 의한 연령별 차이가 나타나지는 않았으나, 만 3 세에서는 스스 로 무게를 확인해보는 유아가 전혀 없었던 반면, 4 세 이상에서 부터 소수 나타났기 때문에, 연령이 증가하면서 실험적 행동 이 증가했다는 측면에서 이전 연구(Ronfard et al., 2018)와 유 사한 점을 보여주었다고 볼 수 있다. 이것은 앞서 설명한 바와 같이 연령이 증가하면서 성인이 주는 정보에 대한 편향적 신 뢰가 감소함에 따라(Jaswal et al., 2010; Ko \& Choi, 2011, 2013; 
Mascaro \& Sperber, 2009), 직관에 반하는 정보를 들었을 때 상 황을 파악하려는 태도가 증가했기 때문일 수 있다.

그럼에도 불구하고, 연구자의 부재 동안 무게를 확인해보려 는 시도가 매우 적었던 것은 인형을 직접 들어봄으로써 연구자 가 준 정보의 진위를 확인해 볼 수 있다는 것에 대해 유아들이 잘 이해하지 못했기 때문일 수 있다. 어떤 방법이나 수단이 있 어야 필요한 정보를 효과적으로 얻을 수 있는지에 대한 분명한 이해는 유아기와 아동기 초반에 걸쳐 발달하는 것으로 나타났 다(Fitneva, Lam, \& Dunfield, 2013; O’Neill, Astington, \& Flavell, 1992; Robinson, Haigh, \& Pendle, 2008). 예를 들어, 만 3, 4세 유 아들은 색깔을 알기 위해서는 눈으로 보아야 하고, 촉감을 알 기 위해서는 손으로 만져 보아야 한다는 것에 대해 잘 분간하 지 못하였다(O’Neill et al., 1992). 이러한 이전 연구의 결과를 기 반으로 추론한다면, 유아기 아동들은 여전히 어떤 방법을 통해 어떤 정보를 습득할 수 있는지에 대한 이해가 성장하는 과정 중에 있기 때문에 인형을 실제로 들어봄으로써 무게를 확인해 보려는 실험적 태도가 적게 나타났을 가능성이 있다.

또는, 본 연구에 사용된 러시안 인형 과업이 유아들의 탐 구 욕구를 충분히 불러일으키지 못했을 가능성도 있다. 이전 연구에서 유아들은 본인의 사전 지식이나 직관에 반하는 정 보를 접하거나 정황이 모호한 상황에서 탐구 행동을 더 많이 보이는 것으로 나타났다(Cook et al., 2011; Legare et al., 2010; Legare, 2012; van Schijindel et al., 2015). 그러나 본 연구의 실험 절차에서는 가장 작은 인형이 가장 무겁다는 직관에 반하는 정보가 한 차례만 제공되었고, 상황의 진위를 판단하고자하는 강한 동기가 야기되지 않았기 때문에 소수의 유아들만이 실험 을 해보았을 수 있다.

한편, 본 연구에서는 자발적 실험 이후 유아의 판단이 변하 는지에 대해서만 살펴본 이전 연구(Ronfard et al., 2018)에서 나아가, 모든 유아에게 인형을 들어 볼 수 있는 기회를 제공하 였고, 그 결과, 인형을 실제로 들어본 이후에는 가장 무거운 인 형이 무엇인지에 대한 판단에 연령에 따른 차이가 없는 것으 로 나타났다. 연구자의 권유로 인형의 무게를 확인해본 직후 에는 대략 만 3 세에서 6 세 전체 유아의 $66 \%$ 가, 종이 위에 올 려 둘 가장 무거운 인형을 골라야 하는 상황에서는 $86 \%$ 의 유 아가 가장 큰 인형이 가장 무겁다고 판단하는 것으로 나타났 다. 이러한 결과는 설사 유아 스스로 상황의 진위를 파악하려 는 시도를 하지 않았다 할지라도 성인이 정보를 확인할 수 있 는 기회를 제공하면 유아들이 직접적 경험에 토대하여 합리적 판단을 내리는 경향이 높아짐을 시사한다. 한 가지 흥미로운 점은, 권유된 실험 직후 가장 무거운 인형이 무엇인지 질문했
던 상황보다 종이를 눌러 놓을 수 있는 가장 무거운 인형을 찾 아야 했던 상황에서 가장 큰 인형을 고르는 유아의 수가 증가 했다는 점이다( $66 \%$ 에서 $86 \%$ 로 증가). 이는 종이를 눌러 놓을 만한 무거운 인형을 골라야 하는 실제적인 상황에서 유아들이 실제 무게를 좀 더 고려하게 되었기 때문으로 볼 수 있다. 따라 서 단순히 인식하거나 언어적으로 응답하는 것보다 실제 상황 에 적용을 해야 하는 경우에 유아들의 합리적인 판단이 증가 할 수 있음을 암시한다.

더불어, 유아들이 인형의 무게에 대해 내리는 판단과 실행기 능, 마음이론간의 관련성에 대해 상관관계 분석을 통해 살펴본 결과, 권유된 실험 전의 유아의 판단은 인지적 억제, 인지적 전 환과 정적 상관이 있는 것으로 나타났다. 또한 연령에 의한 효 과를 통제한 후에는 권유된 실험 전의 유아의 판단과 인지적 전 환 능력만이 관련이 있는 것으로 나타났다. 이러한 결과는 인지 적 억제보다도 인지적 전환이 유아의 판단에 기여할 수 있다는 점을 보여주었다는 측면에서, 인지적 억제의 영향력만을 살펴 보았던 이전 연구에서 한 단계 나아간 결과라고 볼 수 있다.

사실 Jaswal 등(2014)은 Gilbert 등(1990)의 연구에서 제시한 바와 같이 사람은 기본적으로 타인이 주는 정보를 그대로 받 아들이는 경향이 있기 때문에 타인이 주는 정보를 사실이 아닌 것으로 이해하고 거부하기 위해서는 인지적 노력이 필요하다 고 가정하였다. 그리고 2-3세 유아를 대상으로 인지적 억제 능 력과 성인이 주는 정보에 대한 편향적 신뢰 간의 관계를 살펴 보았으나 직접적인 상관은 확인할 수 없었고, 다만 둘 간의 관 련성을 간접적으로 암시할 수 있는 결과를 얻었다. 조금 더 연 령이 높은 만 3세에서 6세 유아들을 대상으로 진행된 본 연구 결과, 성인이 유아의 직관에 반하는 정보를 주는 모호한 상황 에서 유아들이 본인의 직관에 기반을 두고 판단하는 경향은 인지적 억제 능력과 정적 상관이 있는 것으로 나타났다. 사실 Jaswal 등(2014)의 연구에서는 연구자가 직관에 위배되는 정보 를 주고, 이 정보가 틀린 정보라는 것이 반복적으로 드러나는 상황이었던 반면, 본 연구에서는 단순히 직관에 위배되는 정 보만을 주었기 때문에 두 연구를 직접적으로 비교하기 어렵다. 그럼에도 불구하고, Jaswal 등(2014)의 연구와 비교할 때, 본 연 구에서는 타인이 유아의 직관에 반하는 정보를 제공하는 상황 에서 유아들의 판단이 인지적 억제 능력과 관련이 있을 수 있 다는 가능성을 좀 더 직접적으로 보여주었다고는 볼 수 있다. 다만, 연령에 의한 효과를 통제하여 살펴본 이후에는 인지적 억제 능력과 유아들의 판단에 유의한 관련성이 없는 것으로 나 타났다. 따라서 Jaswal 등(2014)과 본 연구의 결과를 종합할 때, 타인이 직관에 반하는 정보를 주는 상황에서 유아가 내리는 판 
단이 인지적 억제 능력과 직접적으로 관련이 있다고 확신하기 에는 무리가 있으며, 좀 더 많은 검증이 필요하다고 본다.

오히려 본 연구에서 중다회귀분석을 통해 살펴본 결과, 여 러 관련 변수의 영향력을 감안한 후에도 인지적 전환 능력이 모호한 상황에서 유아가 내리는 판단을 예측하는 것으로 나타 났다. 구체적으로, 연구자의 권유로 인형의 무게를 직접 확인 하기 전에 유아가 내리는 판단은 인지적 전환 능력과 관련이 있었으나, 연구자의 권유로 무게를 직접 확인한 이후에 유아 들이 내리는 판단은 인지적 전환 능력과 관련이 없었다. 이것 은 무게를 직접 확인해보기 전에는 연구자가 주는 정보와 본 인의 직관에서 오는 정보 사이에서 진위를 판단해야 하는 모 호한 상황이었지만, 무게를 직접 확인한 이후에는 상황에 대 한 판단이 보다 명확해졌기 때문에 인지적 전환 능력이 작용 할 필요가 없었기 때문으로 볼 수 있다. 인지적 전환 능력은 목 표 달성을 위해 본인의 전략이나 생각의 방향을 유연하게 전 환하는 능력을 일컫는데(Dennis et al., 2010), 본 연구의 결과, 모호한 상황에서 연구자가 주는 정보에 무작정 따라가기보다 융통성있게 본인의 직관에서 오는 판단으로 전환하기 위해서 는 인지적 전환 능력이 필요할 수 있다고 볼 수 있다. 따라서 본 연구에서는 직관에 반하는 정보를 듣게 되는 상황에서, 유 아의 인지적 전환 능력이 유아의 판단에 영향을 미칠 수 있다 는 새로운 관점을 제공하였다고 해석된다.

한편 유아들이 내리는 판단은 유아의 마음이론과는 유의한 관련이 없는 것으로 나타났다. 타인이 제공하는 부정확하거나 틀린 정보를 그대로 받아들이지 않고 효과적으로 배우기 위해 서는 정보를 주는 사람의 지식 상태(예: 얼마나 많이, 정확히 알고있는지)나 정직성 등을 고려할 필요가 있다(Sperber et al., 2010). 그러나 정보 제공자의 정신적 상태에 대한 이해가 그 사람이 주는 정보를 받아들일지에 대한 선택이나 수용 정도에 영향을 미칠 수 있음에도 불구하고(Mascaro \& Sperber, 2009; Vanderbilt et al., 2011), 본 연구에서는 마음이론 과업에서 측정 된 유아들의 정신에 대한 이해와 유아들의 판단 간에 별다른 유의한 관련이 없는 것으로 나타났다.

이것은 본 연구의 무게 판단 과업에서는 연구자가 반복해 서 틀린 정보를 제공하거나 의도적으로 속이려는 모습을 보이 지 않아, 유아들이 연구자의 지식 상태나 의도를 비롯한 정신 상태에 대해 추론할 필요가 없었기 때문일 수 있다. 따라서 타 인의 의도나 지식 상태에 대한 직접적 추론을 바탕으로 그 사 람이 제공하는 정보를 판단해야 하는 상황을 살펴본다면 유아 의 마음이론이 정보에 대한 판단에 영향을 미치는지에 대해 좀 더 직접적으로 살펴볼 수 있을 것이다.
마지막으로 본 연구의 의의에도 불구하고, 몇 가지 한계점 에 대해 살펴볼 필요가 있다. 먼저, 본 연구에서는 인지적 억제 보다는 인지적 전환이 유아들이 내리는 판단에 영향을 줄 수 있 는 것으로 나타났으나, 이는 인지적 억제 과업의 난이도가 더 높아 변별력이 높았기 때문일 수도 있다. 따라서 후속 연구에서 두 과업의 난이도나 점수 분포를 유사하게 하여 측정한다면 두 변수의 상대적 중요성을 보다 정밀하게 검증할 수 있을 것이다. 또한 본 연구에서는 유아들이 내리는 판단에 연령에 따른 차이 와 개인적 차이가 있는지를 함께 살펴보았으나, 실행기능과 마 음이론이 유아기동안 연령의 증가와 함께 급격히 발달함을 고 려할 때, 개인적 차이를 보다 면밀하게 살펴보기 위해서는 한 연령대의 유아들을 선정하여 집중적으로 살펴볼 필요가 있다.

더불어 유아가 속한 문화와 가정 배경을 고려한 관련 연구 가 필요할 것으로 생각된다. 중국 아동들을 대상으로 이루어진 이전 연구(Ronfard et al., 2018)와 비교할 때, 본 연구에서는 연 구자가 없을 때 자발적인 실험을 해본 유아가 매우 소수인 것 으로 나타났다. 사실상 직관에 위배되는 정보가 주어지는 모 호한 상황에서 한국 유아들의 판단이나 실험 경향에 대해 살펴 본 연구가 부족한 만큼, 이를 정확히 파악하기 위해서는 다양 한 후속 연구가 필요할 것으로 보인다. 또한 한국 유아들의 인 지적 억제나 전환 능력이 서구 문화권의 유아들보다 빨리 발달 한다고 보고한 결과를 포함하여(Oh \& Lwis, 2008), 동아시아권 에서 성장하는 유아들이 자기통제를 강조하는 양육이나 학교, 사회적 기대 등의 영향으로 실행기능의 측면에서 더 이른 발달 을 보인다고 보여주는 연구들이 있다(Jaramillo, Redón, Muñoz, Weis, \& Trommsdorff, 2017). 따라서 다양한 문화권에서 유아 의 실행기능이 모호한 상황에서의 유아들의 판단이나 실험 경 향에 어떤 관계가 있는지에 대해 살펴본다면 이 변수들간의 관 련성에서 문화적 차이가 나타나는지에 대해 살펴볼 수 있는 기 회가 될 것이다. 마지막으로, 본 연구에서는 마음이론이나 실 행기능이 가정의 소득 수준과 유의한 관련이 없는 것으로 나타 났으나, 이러한 인지적 능력이 가정의 사회경제적 수준과 관련 이 있음을 보고한 연구들이 있다(Blair \& Raver, 2012; Hughes \& Devine, 2016). 본 연구에 참여한 대부분의 유아 가정이 중산층 인 것을 고려할 때, 이후에 보다 다양한 가정의 유아들을 포함 하여 연구를 진행한다면, 가정의 사회 경제적 수준이 유아들의 판단과 실행기능, 마음이론, 그리고 이들 변수 간의 관계에 영 향을 미치는지에 대해 살펴볼 수 있을 것이다.

본 연구는 한국 유아들을 대상으로 성인이 유아의 직관에 반하는 정보를 제공하는 상황에서 유아들이 어떻게 판단을 내 리는지, 그리고 실험적 태도를 보이는지 살펴보고, 이러한 판 
단 과정에 영향을 미칠 수 있는 인지적 요인들에 대해 알아보 았다는 것에 의의가 있다. 본 연구를 포함한 많은 연구들은 유 아 본인의 직접적 경험이나 탐색(Bruner, 1973; Piaget, 1930)과 타인과의 상호작용이나 타인에게서 주어지는 정보(Gelman, 2009; Vygotsky, 1978) 모두 학습에 있어 중요한 기반이 된다는 것을 보여주고 있다. 보다 많은 연구를 통해, 유아가 다른 사람 에게서 얻게 되는 정보와 직접적인 경험을 통해 얻게 되는 정 보 속에서 지식을 어떻게 구성해 나가는지 살펴본다면, 다양 한 정보 속에서 유아가 학습해 나가는 원리와 이러한 학습을 도울 수 있는 방향에 대한 중요한 정보를 얻을 수 있을 것이다.

\section{Notes}

This article is a part of the first author's master's thesis submitted in 2020 .

\section{Conflict of Interest}

No potential conflict of interest relevant to this article was reported.

\section{Ethics Statement}

All procedures of this research were reviewed by IRB (PNU IRB/2020_16_HR).

\section{References}

\section{In English}

Best, J. R., \& Miller, P. H. (2010). A developmental perspective on executive Function. Child Development, 81(6), 16411660. doi:10.1111/j.1467-8624.2010.01499.x

Birch, S. A. J., Vauthier, S. A., \& Bloom, P. (2008). Three-and four-year-olds spontaneously use others' past performance to guide their learning. Cognition, 107(3), 1018-1034. doi:10.1016/j.cognition.2007.12.008

Blair, C., \& Raver, C. C. (2012). Child development in the context of adversity: Experiential canalization of brain and behavior. American Psychologist, 67(4), 309-318. doi: $10.1037 / \mathrm{a} 0027493$

Bruner, J. S. (1973). Organization of early skilled action. Child Development, 44(1), 1-11. doi:10.2307/1127671

Bussey, K. (1999). Children's categorization and evaluation of different types of lies and truths. Child Development, 70(6), 1338-1347. doi:10.1111/1467-8624.00098

Clemént, F., Koenig, M., \& Harris, P. (2004). The ontogenesis of trust. Mind and Language, 19(4), 360-379. doi:10.1111/ j.0268-1064.2004.00263.x

Cook, C., Goodman, N. D., \& Schulz, L. E. (2011). Where science starts: Spontaneous experiments in preschoolers' exploratory play. Cognition, 120(3), 341-349. doi:10.1016/ j.cognition.2011.03.003

Dennis, J. P., \& Vander Wal, J. S. (2010). The cognitive flexibility inventory: instrument development and estimates of reliability and validity. Cognitive Therapy and Research, 34, 241-253. doi:10.1007/s10608-009-9276-4

Faul, F., Erdfelder, E., Buchner, A., \& Lang, A.-G. (2009). Statistical power analyses using $G^{*}$ Power 3.1: Tests for correlation and regression analyses. Behavior Research Methods, 41, 11491160.

Fitneva, S. A., Lam, N. H. L., \& Dunfield, K. A. (2013). The development of children's information gathering: To look or to ask? Developmental Psychology, 49(3), 533-542. doi: $10.1037 / \mathrm{a} 0031326$

Gelman, S. A. (2009). Learning from others: Children's construction of concepts. Annual review of Psychology, 60, 115-140. doi:10.1146/annurev.psych.59.103006.093659

Gerstadt, C. L., Hong, Y. J., \& Diamond, A. (1994). The relationship between cognition and action: Performance of children 3 1/2-7 years old on a stroop-like day-night test. Cognition, 53(2), 129-153. doi:10.1016/00100277(94)90068-X

Gilbert, D. T., Krull, D. S., \& Malone, P. S. (1990). Unbelieving the unbelievable: some problems in the rejection of false information. Journal of Personality and Social Psychology, 59(4), 601-613. doi:10.1037/0022-3514.59.4.601

Harris, P. L., Corriveau, K. H. (2014). Learning from testimony about religion and science. In E. J. Robinson \& S. Einav (Eds.) Trust and skepticism: Children's selective learning from testimony (pp.28-41). Hove, UK: Psychology Press.

Happé, F. G. E. (1994). An advanced test of theory of mind: Understanding of story characters' thoughts and feelings by able autistic, mentally handicapped, and normal children and adults. Journal of Autism and Developmental Disorders, 24(2), 129-154. doi:10.1007/BF02172093

Hughes, C., \& Devine, R. T. (2016). Family influences on theory of mind: A review. In V. Slaughter \& M. de Rosnay (Eds.), Theory of mind development in context (pp. 41-56). London: 
Routledge.

Jaramillo, J. M., Rendón, M. I., Muñoz, L., Weis, M., \& Trommsdorff, G. (2017). Children's self-regulation in cultural contexts: The role of parental socialization theories, goals, and practices. Frontiers in Psychology, 8(923), 1-9. doi:10.3389/fpsyg.2017.00923

Jaswal, V. K., Croft, A. C., Setia, A. R., \& Cole, C. A. (2010). Young children have a specific, highly robust bias to trust testimony. Psychological Science, 21(10), 1541-1547. doi:10.1177/0956797610383438

Jaswal, V. K., \& Malone, L. S. (2007). Turning believers into skeptics: 3-year-olds' sensitivity to cues to speaker credibility. Journal of Cognition and Development, 8(3), 263-283. doi:10.1080/15248370701446392

Jaswal, V. K., \& Neely, L. A. (2006). Adults don't always know best: Preschoolers use past reliability over age when learning new words. Psychological Science, 17(9), 757-758. doi:10.1111/ j.1467-9280.2006.01778.x

Jaswal, V. K., Pérez-Edgar, K., Kondrad, R. L., Palmquist, C. M., Cole, C. A., \& Cole, C. E. (2014). Can't stop believing: Inhibitory control and resistance to misleading testimony. Developmental Science, 17(6), 965-976. doi:10.1111/ desc. 12187

Legare, C. H. (2012). Exploring explanation: Explaining inconsistent information guides hypothesis-testing behavior in young children. Child Development, 83(1), 173-185. doi:10.1111/j.1467-8624.2011.01691.x

Legare, C. H., Gelman, S. A., \& Wellman, H. M. (2010). Inconsistency with prior knowledge triggers children's causal explanatory reasoning. Child Development, 81(3), 929-944. doi:10.1111/j.1467-8624.2010.01443.x

Lucas, A. J., Lewis, C., Pala, F. C., Wong, K., \& Berridge, D. (2013). Social-cognitive processes in preschoolers' selective trust: Three cultures compared. Developmental Psychology, 49(3), 579-590. doi:10.1037/a0029864

Mascaro, O., \& Sperber, D. (2009). The moral, epistemic, and mindreading components of children's vigilance towards deception. Cognition, 112(3), 367-380. doi:10.1016/ j.cognition.2009.05.012

Moore, C., Barresi, J., \& Thompson, C. (2001). The cognitive basis of future-oriented prosocial behavior. Social Development, 7(2), 198-218. doi:10.1111/1467-9507.00062

Oh, S., \& Lewis, C. (2008). Korean preschoolers' advanced inhibitory control and its relation to other executive skills and mental state understanding. Child Development, 79(1), 80-99. doi:10.1111/j.1467-8624.2007.01112.x

O’Neill, D. K., Astington, J. W., \& Flavell, J. H. (1992). Young children's understanding of the role that sensory experiences play in knowledge acquisition. Child Development, 63(2), 474-490. doi: $10.2307 / 1131493$
Piaget, J. (1930). The child's conception of physical causality. London: Routledge.

Robinson, E. J., Haigh, S. N., \& Pendle, J. E. C. (2008). Children's working understanding of the knowledge gained from seeing and feeling. Developmental Science, 11(2), 299305. doi:10.1111/j.1467-7687.2008.00676.x

Ronfard, S., Chen, E. E., \& Harris, P. L. (2018). The emergence of the empirical stance: Children's testing of counterintuitive claims. Developmental Psychology, 54(3), 482-493. doi: $10.1037 / \operatorname{dev} 0000455$

Sperber, D., Clément, F., Heintz, C., Mascaro, O., Mercier, H., Origgi, G., \& Wilson, D. (2010). Epistemic vigilance. Mind \& Language, 25(4), 359-393. doi:10.1111/j.14680017.2010.01394.x

Vanderbilt, K. E., Liu, D., \& Heyman, G. D. (2011). The development of distrust. Child Development, 82(5), 13721380. doi:10.1111/j.1467-8624.2011.01629.x

van Schijndel, T. J. P., Visser, I., van Bers, B. M. C. W., \& Raijmakers, M. E. J. (2015). Preschoolers perform more informative experiments after observing theory-violating evidence. Journal of Experimental Child Psychology, 131, 104-119. doi:10.1016/j.jecp.2014.11.008

Vygotsky, L. S. (1978). Mind in society: The development of higher psychological processes. Cambridge, MA: Harvard University Press.

Wellman, H. M., \& Liu, D. (2004). Scaling of theory-of-mind tasks. Child Development, 75(2), 523-541. doi:10.1111/ j.1467-8624.2004.00691.x

Zelazo, P. D. (2006). The Dimensional Change Card Sort (DCCS): A method of assessing executive function in children. Nature Protocols, 1, 297-301. doi:10.1038/nprot.2006.46

\section{In Korean}

Chung, S., \& Choi, Y. (2013). Does same-sex preference make 3-4-year-olds more gullible? The Korean Journal of Developmental Psychology, 26(4), 93-105.

Gwon, E.-Y., \& Lee, H. (2012). Development of deception, false belief and executive function in children. The Korean Journal of Developmental Psychology, 25(2), 165-184.

Jeong, J. (2018). Who do I need to trust between a teacher and a peer? Young childrens selective trust when the teachers accuracyis low or uncertain. The Korean Journal of Developmental Psychology. 31(4), 43-58. doi:10.35574/ kjdp.2018.12.31.4.43

Jeong, S., \& Choi, Y. (2017). The influence of informants age in selective trust of Korean children. The Korean Journal of Developmental Psychology, 30(3). 67-82.

Ko, Y., \& Choi, Y. (2011). Three and four year-olds' use of 
observation experience in judging an informant's accuracy. The Korean Journal of Developmental Psychology, 24(4), 151162.

Ko, Y., \& Choi, Y. (2013). Re-examination of 3-year-old's bias to trust others' testimony. The Korean Journal of Developmental Psychology, 26(1), 197-214.

\section{ORCID}

Yuri Jeong https://orcid.org/0000-0003-2849-0737

Jeein Jeong http://orcid.org/0000-0002-5130-4624

Received April 28, 2021

Revision received June 9, 2021

Accepted June 19, 2021 